\title{
HNPS Advances in Nuclear Physics
}

Vol 21 (2013)

\section{HNPS2013}

Helienic Nuciear

Physics Society

\section{HNPS:}

Advances in Nuclear Physics

Proceedings of the 22nd Hellente Conference an Mueleor Physict

Eallors

C. Mortamets

A Q Oodalisos

G. Soutotir
Sediment pollution by radionuclides and toxic metals in the lerissos Gulf, North Aegean Sea, Greece

F. K. Pappa, C. Tsabaris, H. Kaberi, C. Zeri, E. Androulakaki, E. Pashalidis, A. Ioannidou, M. Kokkoris, G. Eleftheriou, D. L. Patiris, R. Vlastou

doi: $10.12681 /$ hnps.2021

To cite this article:

Pappa, F. K., Tsabaris, C., Kaberi, H., Zeri, C., Androulakaki, E., Pashalidis, E., loannidou, A., Kokkoris, M., Eleftheriou, G., Patiris, D. L., \& Vlastou, R. (2019). Sediment pollution by radionuclides and toxic metals in the lerissos Gulf, North Aegean Sea, Greece. HNPS Advances in Nuclear Physics, 21, 148-152. https://doi.org/10.12681/hnps.2021 


\title{
Sediment pollution by radionuclides and toxic metals in the Ierissos Gulf, North Aegean Sea, Greece
}

\author{
F.K. Pappa ${ }^{\mathrm{a}, \mathrm{b}}$, C. Tsabaris ${ }^{\mathrm{a}}$, H. Kaberi ${ }^{\mathrm{a}}$, C. Zeri ${ }^{\mathrm{a}}$, E. Androulakaki ${ }^{\mathrm{a}, \mathrm{b}}$, E. Pashalidis $^{\mathrm{c}}$, A. Ioannidou $^{\mathrm{d}}$, \\ M. Kokkoris ${ }^{\mathrm{b}}$, G. Eleftheriou ${ }^{\mathrm{a}, \mathrm{b}}$, D.L. Patiris ${ }^{\mathrm{a}}$, R. Vlastou $^{\mathrm{b}}$ \\ ${ }^{a}$ Institute of Oceanography, Hellenic Centre for Marine Research, 19013 Anavyssos, Greece \\ ${ }^{b}$ Department of Physics, National Technical University of Athens, 15780 Zografou, Greece \\ ${ }^{c}$ Department of Chemistry, University of Cyprus, P.O. Box 20537, 1678 Lefkosia, Cyprus \\ ${ }^{d}$ Physics Department, Nuclear Physics and Elementary Particle Physics Division, Aristotle University of Thessaloniki, \\ Thessaloniki 54124, Greece
}

\begin{abstract}
Environmental pollution of industrial areas and especially of areas which contain industries that involve processing of NORM (Naturally Occurring Radioactive Materials), requires monitoring radionuclide activities and trace metal concentration. In the gold mine facility of Stratoni region in Ierissos Gulf, surface sediment samples were analysed regarding TENORM (Technologically Enhanced NORM) and toxic metals (e.g. $\mathrm{As}, \mathrm{Pb}, \mathrm{Cu}, \mathrm{Cr}$ and $\mathrm{Ni}$ ). Radionuclide activity concentrations $\left({ }^{226} \mathrm{Ra},{ }^{214} \mathrm{~Pb},{ }^{214} \mathrm{Bi},{ }^{210} \mathrm{~Pb},{ }^{228} \mathrm{Ac}\right.$, $\left.{ }^{212} \mathrm{~Pb},{ }^{212} \mathrm{Bi},{ }^{208} \mathrm{Tl},{ }^{40} \mathrm{~K}\right)$ were measured by means of gamma-ray spectrometry using a high-purity germanium (HPGe) detector, while the trace metals concentrations were determined using the XRF (X-Ray Fluorescence) technique. The results indicate that the surface sediments of the Ierissos Gulf are significantly polluted with $\mathrm{As}, \mathrm{Pb}$ and $\mathrm{Cu}$. Surface distribution analysis of the studied radionuclides and toxic metals (e.g. TENORM, $\mathrm{As}, \mathrm{Pb}$, and $\mathrm{Cu}$ ) indicates maximum contamination levels close to the factory area, which decrease gradually with increasing distance from the shore. The interpretation of the increased levels is under investigation since the load-out facility of the mining operations in the town of Stratoni affects the whole ecosystem.
\end{abstract}

Keywords: Heavy metals, Stratoni, gamma-ray spectrometry, gold mine

\section{Introduction}

Mine processing ends up with large amounts of by-products, mainly originating during the chemical separation of the metal from the ore. Mining involves both open-cut and underground operations. The ore is crushed, panned and the remaining waste rock is dumped into heaps as tailings [1]. The residual material contains natural radionuclides that are found in the rock itself since the bearing ore is often associated with enhanced uranium concentrations [2]. Moreover, the residual material may also contain quantities of heavy metals (e.g. As) due to the process of the metal separation from the ore.

More specifically gold mining plants are active in many areas worldwide and they are considered as areas that may cause pollution due to the $\mathrm{U}$ bearing tailings and the heavy metals release to the environment (e.g. $\mathrm{Pb}$ and $\mathrm{As}$ ) [2-4]. As and $\mathrm{Pb}$ are considered hazardous substances and are the dominant metals found in gold-sulfide deposits, since they are the main contained minerals in arsenopyrite (FeAsS) and galena $(\mathrm{PbS})$, respectively. Under natural conditions, they are relatively stable. However, if mining processing are involved, the minerals are broken down due to the exposure to oxygen and water [3].

The research performed in areas with mining activities concerns mostly the terrestrial and not the marine environment. As far as radionuclides in seawater nd sediments are concerned there is a lack in literature regarding their spatial and temporal evolution. Nevertheless, marine sediments are a major repository of heavy metals in coastal areas and their study plays an important role in the quality assessment of the marine environment. Moreover, the geochemistry of the sediments plays an important role in the study of pollution 
pattern of soils. Metals prefer the sediment phase, thereby facilitating the elimination of metals from the water column thus sediments serve as sinks to metals. However, the metals can be released back to the water when changes in the environment occur, such as changes in the $\mathrm{pH}$, redox potential or the presence of organic materials [4].

According to a previous study [5], surface sediment samples from Strymonikos and Ierissos Gulfs were analyzed for $\mathrm{Cu}, \mathrm{Pb}, \mathrm{Zn}, \mathrm{Cr}$ and $\mathrm{Ni}$ concentrations. The sea-bottom area located at the load-out facility of the mining operations in the town of Stratoni (Ierissos Gulf) was established as the most polluted region. However, the activity levels in the marine environment in the specific area have not been reported. The coastal marine ecosystems of Strymonikos and Ierissos Gulfs (Fig. 1) are commercial fishing grounds (trawling is not allowed in the Ierissos Gulf) and are adjacent to areas of important industrial and agricultural activities [5]. Any potential pollution affects directly the human health and marine life, while, indirectly, it may cause disequilibrium to the marine species, bio-societies and food chain. In this study surface sediment samples from the mine area of Stratoni and the adjacent area have been analyzed for TENORM and toxic metals, in an attempt to study the possible impact of human activities in the area.

\section{Study area and methodology}

The Stratoni area is situated in the Chalkidiki Peninsula, northern Greece (Fig. 1). The study area lies between latitudes $40^{\circ} 30$ and $40^{\circ} 32.5$ and longitudes $23^{\circ} 45$ and $23^{\circ} 32.5$. It is characterized by a mountainous relief with $92 \%$ of the surface covered by forest. Starting at $10 \mathrm{~km}$ west of Stratoni village, a $\mathrm{P}-\mathrm{Zn}-\mathrm{Mn}$ deposit is present and exploited in the Varvara Mine. Moving eastwards along the StratoniVarvara fault, $\mathrm{Pb}-\mathrm{Zn}$ sulfide ore forms within the marble as well as along the contact between the gneiss and the lower marble horizon. Major deposits of this type have been exploited at Madem Lakkos, Olympias and Mavres Petres mines. The major minerals present in the Stratoni deposit are pyrite, arsenopyrite, galena and rhodochrosite. Copperiferous pyrite has also been extracted at Madem Lakkos during the 1970s. Another ore type of the area is the porphyric $\mathrm{Cu}-\mathrm{Au}$ deposits in Skouries and Fisoka, south of Stratoni village. Major minerals present in this ore are pyrite, chalcopyrite, bornite and magnetite [6].

It should be noted here that mining activity dates back to prehistoric times and continues until today. During the last century, several mining companies exploited the sulfide and manganese ore deposits of the wider area (Madem Lakkos, Mavres Petres and Piavitsa ore bodies) extracting million of tons of mixed sulfide, manganese oxide and pyrite. Acid mine water, deriving from both Mavres Petres and Madem Lakkos mines, is directed to the water treatment plant, located next to the Stratoni flotation plant where treatment is carried out in agitated reactors with hydrated lime $\left(\mathrm{Ca}(\mathrm{OH})_{2}\right)$ for neutralization. Mine waste and fine grained tailings, produced by the flotation procedure, are disposed at the controlled Chevalier site, next to Stratoni village. Coarse grained tailings mixed with cement and water are commonly used for backfilling the mining shafts and adits [7].

A total of 9 surficial marine sediments (upper $2 \mathrm{~cm}$ layer) were collected from Ierissos Gulf (STRAS 1, 2, $3,4,5,6,7,8,9)$. One sample was collected in the area of the load out pier of the mining plant (STRAS 4), five samples (STRAS 1, 2, 3, 5, 6) were collected from the neighboring sites (Stratoni region), two samples (STRAS 7, 8) near Kokkinolakkos River estuary and STRAS 9, near Ierissos region (away from Stratoni region and Kokkinolakkos River). Sample STRAS9 can be thought as being a reference sample.

The samples were processed by a standard procedure including drainage, sieving and pulverization, so as to achieve a homogeneous powder with a maximum grain size of $63 \mu \mathrm{m}$. The samples remained tightly closed to their final boxes (geometry: $68 \mathrm{~mm}$ inner diameter and $18 \mathrm{~mm}$ inner height) for at least 21 days in order to achieve secular equilibrium between Radon daughters and ${ }^{226} \mathrm{Ra}$. The measurements were carried out by means of a High Purity Germanium (HPGe) detector. The spectrum analysis was performed using the SPECTRW spectroscopy software package [8].

The trace elements concentrations were determined in three sediment samples (STRAS3, 4 and 7) using the XRF technique. Only for the sample STRAS3, a grain size separation was performed prior to the XRF analysis. More specifically, two samples were prepared, with a grain size distribution ranging from $63 \mu \mathrm{m}$ to $2 \mathrm{~mm}$ grain diameter (STRAS3_2) and a second sample (STRAS3_63) which included only grains with 


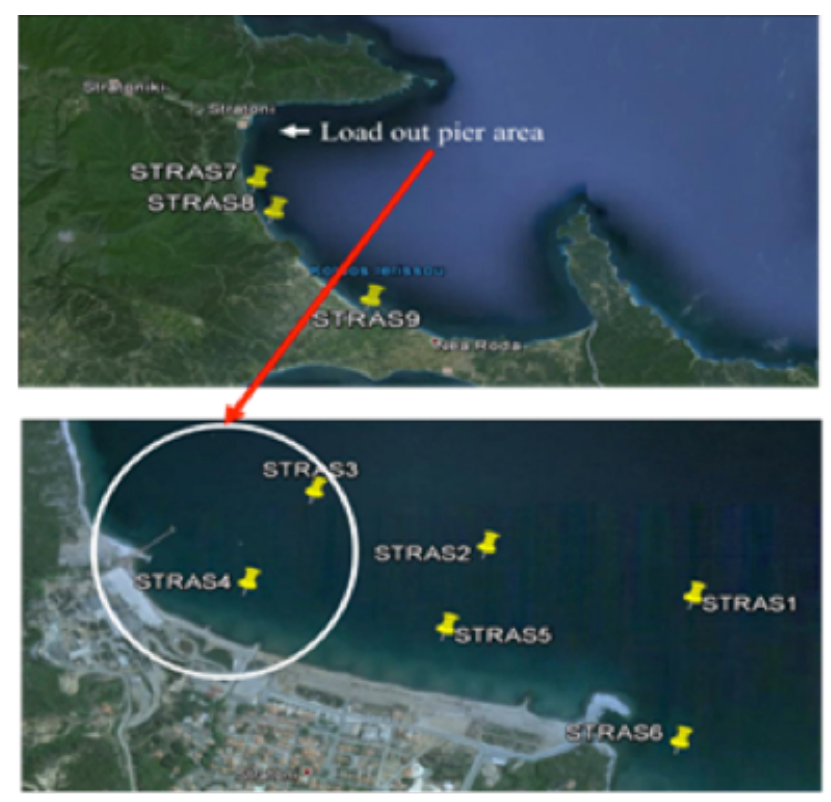

Figure 1: The sampling locations from Ierissos Gulf focused at Stratoni region.

diameter smaller than $63 \mu \mathrm{m}$. In this way the preference of the absorption in different grain size clusters was additionally studied.

The activity concentrations (in units $\mathrm{Bq} / \mathrm{kg}$ ) were calculated by analyzing the gamma-ray spectra using the following 1 formula [7].

$$
\text { Activity }=\frac{\text { counts }}{\text { eff } \cdot t \cdot m \cdot I_{\gamma}}
$$

where:

$t$ is the time measurement of each sample $(24 \mathrm{~h})$,

eff: the absolute photopeak efficiency

$m$ : the mass (in $\mathrm{kg}$ ) of each sediment sample

$I_{\gamma}$ : the emission probability of the gamma-ray lines of interest.

The efficiency calibration of the HPGe detector was performed using a reference ${ }^{152} \mathrm{Eu}$ source. Among the analyzed photopeaks there was a case of two folded photopeaks at $185.71 \mathrm{keV}\left({ }^{235} \mathrm{U}\right)$ and at $186.21 \mathrm{keV}$ $\left({ }^{226} \mathrm{Ra}\right)$. Assuming that ${ }^{238} \mathrm{U}$ and ${ }^{226} \mathrm{Ra}$ are in secular equilibrium and using: (a) the known relative abundance in nature of the two Uranium isotopes $\left(99.3 \%\right.$ for ${ }^{238} \mathrm{U}$ and $0.7 \%$ for ${ }^{235} \mathrm{U}$ ); and (b) the decay branching in each case, one can readily calculate the expected detected relative intensity of the two gammas (0.43 and 0.57 for the $185.71 \mathrm{keV}$ and the $186.21 \mathrm{keV}$, respectively).

\section{Results and discussion}

The results of the activity $(\mathrm{Bq} / \mathrm{kg})$ and the trace element $(\mu \mathrm{g} / \mathrm{gr})$ concentrations are depicted in Fig. 2 .

Arsenic concentrations ranged from 340 to $4094 \mu \mathrm{g} / \mathrm{g}$, Pb from 789 to $2988 \mu \mathrm{g} / \mathrm{g}$ and $\mathrm{Cu}$ from 54 to $336 \mu \mathrm{g} / \mathrm{g}$. Enhanced activity levels were observed for the radionuclides of the ${ }^{238} \mathrm{U}$ decay series. The activity of ${ }^{226} \mathrm{Ra}$ was found to range between 21 and $121 \mathrm{~Bq} / \mathrm{kg}$, while the activity of the ${ }^{222} \mathrm{Rn}$ daughters $\left({ }^{214} \mathrm{~Pb}\right.$, ${ }^{214} \mathrm{Bi}$ ) from 20 to $101 \mathrm{~Bq} / \mathrm{kg}$. Furthermore, concerning the ${ }^{232} \mathrm{Th}$ series, the activity of ${ }^{228} \mathrm{Ac}$ varied from 21 to $35 \mathrm{~Bq} / \mathrm{kg}$, while the ${ }^{220} \mathrm{Rn}$ daughters $\left({ }^{212} \mathrm{~Pb},{ }^{212} \mathrm{Bi},{ }^{208} \mathrm{Tl}\right)$ from 22 to $35 \mathrm{~Bq} / \mathrm{kg}$. As concerns ${ }^{40} \mathrm{~K}$ and ${ }^{210} \mathrm{~Pb}$, their activities varied from 423 to $634 \mathrm{~Bq} / \mathrm{kg}$ and from 57 to $126 \mathrm{~Bq} / \mathrm{kg}$, respectively. 


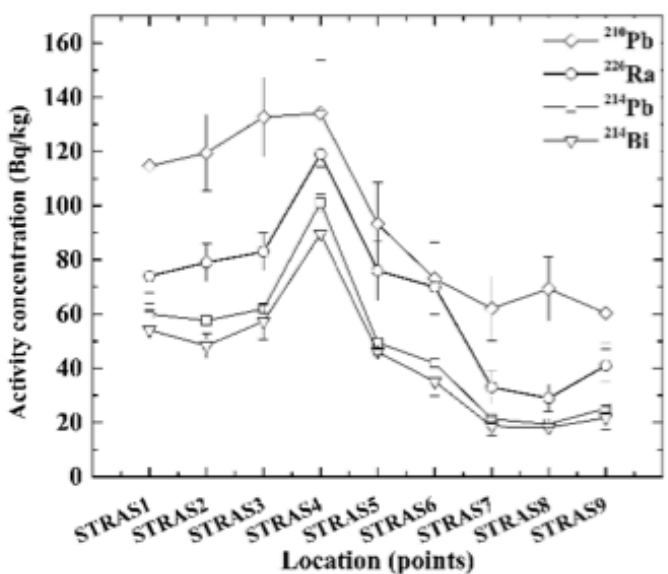

a.) The ${ }^{238} \mathrm{U}$ series

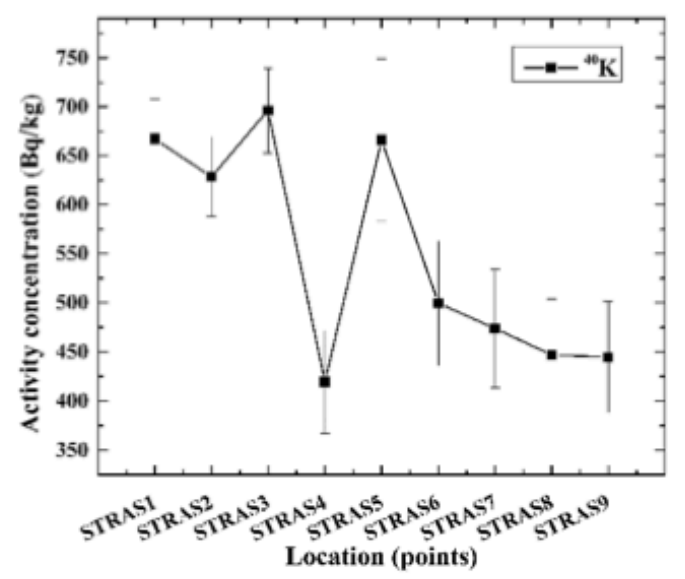

c.) The radionuclide ${ }^{40} \mathrm{~K}$

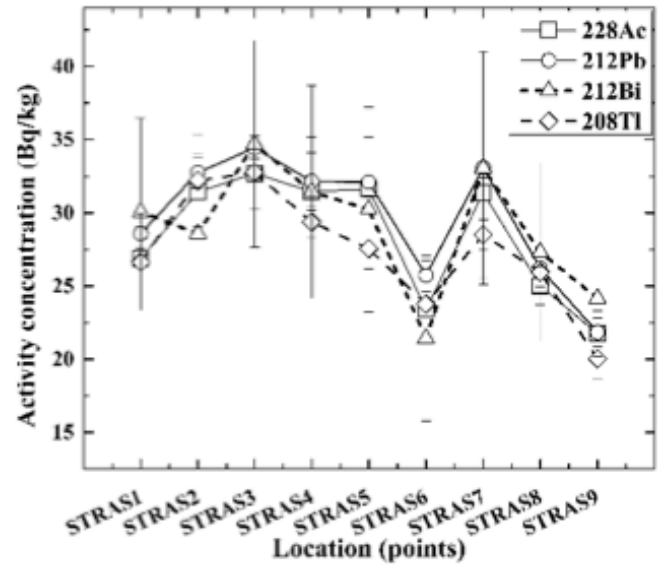

b.) The ${ }^{232} \mathrm{Th}$ series

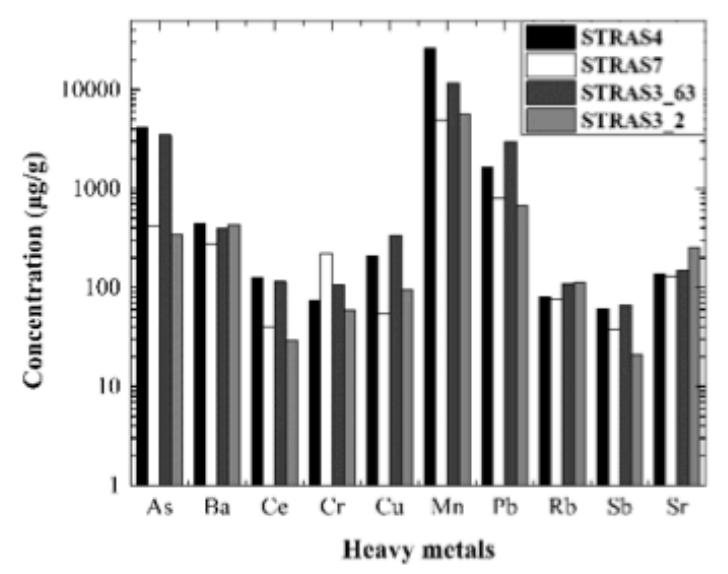

d.) Trace element (As, $\mathrm{Ba}, \mathrm{Ce}, \mathrm{Cr}, \mathrm{Cu}, \mathrm{Mn}, \mathrm{Pb}$, $\mathrm{Rb}, \mathrm{Sb}$ and $\mathrm{Sr}$ ) concentrations

Figure 2: The activity and trace metal concentrations for all the measured sediment samples.

The activity levels of the ${ }^{238} \mathrm{U}$ daughters were found to be enhanced mainly in the area of the load out pier of the mining plant (STRAS4), while the observed activity levels in the neighboring sites (STRAS 1, 2, $3,5,6)$ were $35-40 \%$ lower.

Enhanced concentrations of $\mathrm{Pb}, \mathrm{As}, \mathrm{Mn}$ and $\mathrm{Cu}$ were also found in the area of the load out pier of the mining plant (STRAS4). Off the pier area (STRAS7) the same elements exhibited much lower concentrations (decreased by one order of magnitude). The results (except for As and $\mathrm{Mn}$ ) are comparable with recent corresponding measurements in the local water streams sediments [7] indicating weathering / transportation via the streams that flow into the gulf. The As and Mn concentration values in the marine sediments were found higher compared to the values reported in the literature [9] especially in the sites close to the load out pier area (STRAS3, 4). 


\section{Conclusions}

In this work, the preliminary results of the trace metals and the radionuclide concentrations were presented. Further analysis to determine the grain size distribution and the mineralogy in the collected sediment samples will be performed.

According to this work the need of systematic monitoring programs throughout the coastal line was emphasized and especially near coastal areas of intense anthropogenic activities (industries, agriculture, aquaculture, mining etc.).

\section{Acknowledgments}

I would like to express my gratitude to Dr. C.K. Kalfas for providing the SPECTRW spectrometry software package and his continuous help. This work was supported by GSRT (Hellenic General Secretariat for Research and Technology) in the frame of the project "RADIOSCOPIO: Research and development of an in-situ underwater gamma-ray spectrometer for low-level radioactivity measurements" under Greece-China Bilateral R\&TD Cooperation 2012-2014.

\section{References}

[1] Panagopoulos, I., Karayannis, A., Adam, K., Aravossis, K., "Application of risk management techniques for the remediation of an old mining site in Greece", Waste Management 29 (2009) 17391746

[2] Lindsay, R., de Meijer, R.J., Newman, R.T., Motlhabane, T.G.K., Maleka, P. "Monitoring the radon flux from goldmine dumps by gamma ray mapping", Nuclear Instruments and Methods in Physics Research B 213, 775 778, (2004)

[3] Ogala, J. S., Mitullah, W. V., Omulo, M. A., "Impact of Gold mining on the Environment and Human Health: A Case Study in the Migori Gold Belt, Kenya", Environmental Geochemistry and Health, Vol. 24, pp. 141-157 (17), (2002)

[4] Getaneh, W., Alemayehu, T., "Metal contamination of the environment by placer and primary gold mining in the Adola region of southern Ethiopia", Environmental Geology 50: 339-352, (2006)

[5] Stamatis, N., Ioannidou, D., Christoforidis, A., Koutrakisi, E., "Sediment pollution by heavy metals in the Strymonikos and Ierissos Gulfs, North Aegean Sea, Greece", Environmental Monitoring and Assessment, 80: 3349, (2002)

[6] Kelepertzis E., Argyraki, A., Alexakis, D., "Multivariate statistics and spatial interpretation of geochemical data for assessing sil contamination by potentially toxic elements in the mining area of Stratoni, north Greece", Geochemistry Exploration Environment Analysis, Vol. 6, pp. 349-355, (2006)

[7] Kelepertzis E., Argyraki A., Daftsis E., "Geochemical signature of surface water and stream sediments of a mineralized drainage basin at NE Chalkidiki, Greece: A pre-mining survey", Journal of Geochemical Exploration 114 pp. $70-81$, (2012)

[8] Kalfas, C. A., "A modern spectroscopy software package", Proceed. for 20th Conf. of the Hellenic Nuclear Physics Society, 27-28 May 2011, Athens, Greece

[9] Anagnostakis M.J., Hinis E.P., Simopoulos S.E., "238 U and its daughter products in Greek surface soils", Radioactivity in the Environment (2005) vol.7 pp. $175-186$ 